\title{
Immunological Aspects of Patients Infested with Scabies in Thi-Qar Province, Southern Iraq
}

\author{
Zainab Abd Ali Mohammad ${ }^{1}$, Nadia Ahmed Hadi², Ahmed Abdulhussein Kawen ${ }^{3}$ \\ ${ }^{1}$ Asst.Prof., ${ }^{2}$ Lecturer Biology Department, College of Education for Pure Science, University of Thi-Qar, Iraq, \\ ${ }^{3}$ Asst. Prof., MBChB, FIBMS/ Department of Venereology and Dermatology, College of Medicine, University of \\ Thi-Qar, Iraq
}

\begin{abstract}
Scabies is skin disease of human and many mammalian hosts caused by the important obligate parasites Sarcoptes scabiei, lives and reproduces in epidermis, resulting a significant human and animal morbidity.

The current study aimed to determine the immunological responses in patients infested with scabies who attended a private clinic in Al-Hussein general hospital in Thi-Qar province. The total white blood cell count, differential counts (lymphocytes, monocytes, neutrophils, eosinophils and basophils), the serum levels of IL-5 and IL-13 in were evaluated in all patients with scabies and compared with non-infested healthy individuals as a control group.

The present study showed significant increase on the mean of total WBC in patients infested with scabies when compared with control $(\mathrm{P} \leq 0.05)$.

A significant differences $(\mathrm{P} \leq 0.05)$ were recorded in the absolute leukocytes counts for patient infested with scabies when compared with control group except that for monocytes and basophils which were nonsignificant $(\mathrm{P} \leq 0.05)$ in our study.

The results of study showed significant differences $(\mathrm{P} \leq 0.05)$ in the mean of IL-5 and IL-13 serum levels for the patient infested with scabies when compared with control.
\end{abstract}

Keywords: Scabies, WBC, IL-5, IL-13, Thi-Qar province, Iraq

\section{Introduction}

Scabies is skin disease of human and many mammalian hosts caused by the obligate ectoparasites Sarcoptes scabiei lives and reproduces in the epidermis that may lead to significant human and animal morbidity [1].

Adult female of the mites reside in burrows within the stratum granulosum of the epidermis and caused many clinical manifestations appear after 48 weeks like itching, irritation, redness for the skin, and hypersensitivity reactions. The clinical rash and itch present as papules or vesicles that may contain individual mites, eggs, egg cases, mite fecal pellets, and debris present in the burrow ${ }^{[2]}$.
The sources of irritation are feeding activity of mite and host immune system response to its secretions and fecal matter that lead to scratching, scabbing, and subsequent secondary infections ${ }^{[3]}$. The infection with this ectoparasite caused stimulation humeral and cellular immune system of host ${ }^{[4]}$.

The circulating antibodies in the skin and the cellmediated immune reaction play a role in clearing of the mites and their eggs and debris.

The intensity of inflammatory response varied with combinations of histiocytes, lymphocytes, and polymorphonuclear leukocytes ${ }^{[2]}$.

The current study aimed to determine the immunological responses in patients infested with 
scabies. The total white blood cell count, differential counts (lymphocytes, monocytes, neutrophils, eosinophils and basophils), the serum levels of IL-5 and IL-13 were evaluated in sixty patients with scabies with no secondary infection or other parasitic infestations and compared with sixty non-infested healthy individuals as control group.

\section{Materials \& Method}

The current study involved 60 patients with scabies had a clinical and microscopically feature of the disease, they attended a private clinic in Al-Hussein general hospital in Thi-Qar province during three months from July to september 2019. The epidermis over the suspected site of scabies infestation was scraped off and the skin scraping performed by placing a drop of microscope immersion oil. The specimen placed on a microscope slide and examined by light microscopy for the demonstration of mites or eggs . Sixty healthy persons were selected as control, with exclusion of any patient in both groups who gave a history of drug ingestion for the last two months.

Five $\mathrm{ml}$ of venous blood were collected from each scabies patients and control group, the blood sample divided into two parts, the first part was collected in tubes with ethylene diamine tetra acetic acid $(2 \mathrm{ml})$ to estimate total white blood cell count (WBC) and differential leukocyte count. The second part $(3 \mathrm{ml})$ were allowed to clot, then centrifuged to separate the serum which stored at $-20{ }^{\circ} \mathrm{C}$ to be used for immunological investigations [5].

The statistical package for social science (SPSS) version used in the current study to analyze data and the results expressed as (Mean \pm S.E.). Independent sample $\mathrm{T}$ - test used to determine the statistical differences by consideration P-value $\leq 0.05$ was statistically significant.

\section{Results}

Results of this study showed significant increase ( $\mathrm{P} \leq 0.05)$ in the mean of total WBC for patients infested with scabies $11.95 \pm 0.18\left(10^{3} / \mathrm{ml}\right)$ when compared with control $5.91 \pm 0.29\left(10^{3} / \mathrm{ml}\right)$.

The absolute leukocytes counts for patient infested with scabies recorded in current study: Lymphocytes $33.90 \pm 1.31\left(\right.$ cell $\left./ \mathrm{mm}^{3}\right)$, monocytes $2.10 \pm 0.26$ (cell/ $\left.\mathrm{mm}^{3}\right)$, neutrophils $71.95 \pm 0.46\left(\right.$ cell $\left./ \mathrm{mm}^{3}\right)$, eosinophils $0.41 \pm 0.21\left(\mathrm{cell} / \mathrm{mm}^{3}\right)$ and basophils $0.096 \pm 0.03$ (cell/ $\mathrm{mm}^{3}$ ), while for control group: Lymphocytes $20.00 \pm$ $0.27\left(\mathrm{cell} / \mathrm{mm}^{3}\right)$, monocytes $2.20 \pm 0.22\left(\mathrm{cell} / \mathrm{mm}^{3}\right)$, neutrophils $59.00 \pm 0.70\left(\right.$ cell $\left./ \mathrm{mm}^{3}\right)$, eosinophils $1.90 \pm$ $0.16\left(\mathrm{cell} / \mathrm{mm}^{3}\right)$ and basophils $0.40 \pm 0.11\left(\mathrm{cell} / \mathrm{mm}^{3}\right)$.

A significant differences $(\mathrm{P} \leq 0.05)$ were recorded in the absolute leukocytes counts for patient infested with scabies when compared with control except that for monocytes and basophils which were non-significant $(\mathrm{P} \leq 0.05)$ in present study. Table 1.

Table 1. Mean \pm S.E of total and absolute leukocytes counts for scabies patients and controls.

\begin{tabular}{|l|l|l|l|}
\hline Parameters & Patients No. 60 & Control No. 60 & P-value \\
\hline $\begin{array}{l}\text { WBC } \\
(103 / \mathrm{ml})\end{array}$ & $11.95 \pm 0.18$ & $5.91 \pm 0.29$ & 0.000 \\
\hline Lymphocytes (cell/mm3) & $33.90 \pm 1.31$ & $20.00 \pm 0.27$ & 0.000 \\
\hline Monocytes (cell/mm3) & $2.10 \pm 0.26$ & $2.20 \pm 0 . .22$ & 0.773 \\
\hline Neutrophils (cell/mm3) & $71.95 \pm 0.46$ & $59.00 \pm 0.70$ & 0.000 \\
\hline Eosinophils (cell/mm3) & $4.35 \pm 0.36$ & $1.90 \pm 0.16$ & 0.000 \\
\hline Basophils (cell/mm3) & $0.25 \pm 0.09$ & $0.40 \pm 0.11$ & 0.324 \\
\hline
\end{tabular}


Results showing significant differences ( $\mathrm{P} \leq 0.05$ ) in the mean of IL-5 serum levels for the patient infested with scabies $330.05 \pm 6.153(\mathrm{pg} / \mathrm{ml})$ when compared with control $171.92 \pm 3.19(\mathrm{pg} / \mathrm{ml})$.
A significant differences $(\mathrm{P} \leq 0.05)$ were noticed in the mean of serum IL-13 levels for the patient infested with scabies $336.94 \pm 9.74(\mathrm{pg} / \mathrm{ml})$ when compared with control $135.29 \pm 4.62$ (pg/ml). Table 2, Fig. 1 and Fig. 2.

Table 2: Mean \pm S.E of the IL-5 and IL-13 in serum for patients infested with scabies and controls.

\begin{tabular}{|l|l|l|l|}
\hline Parameters & Patients No. 60 & Control No. 60 & P-value \\
\hline IL $5(\mathrm{pg} / \mathrm{ml})$ & $330.05 \pm 6.153$ & $171.92 \pm 3.19$ & 0.000 \\
\hline IL $13(\mathrm{pg} / \mathrm{ml})$ & $336.94 \pm 9.74$ & $135.29 \pm 4.62$ & 0.000 \\
\hline
\end{tabular}

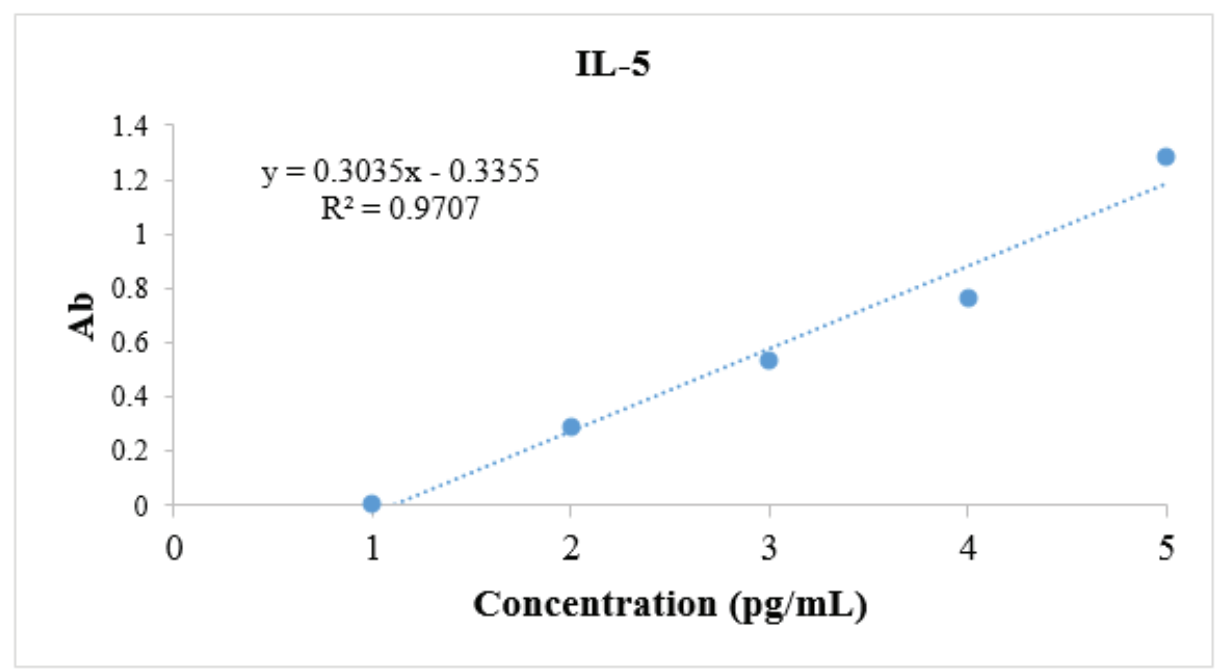

Fig. 1. Concentrations of IL-5 in patients infested with scabies.

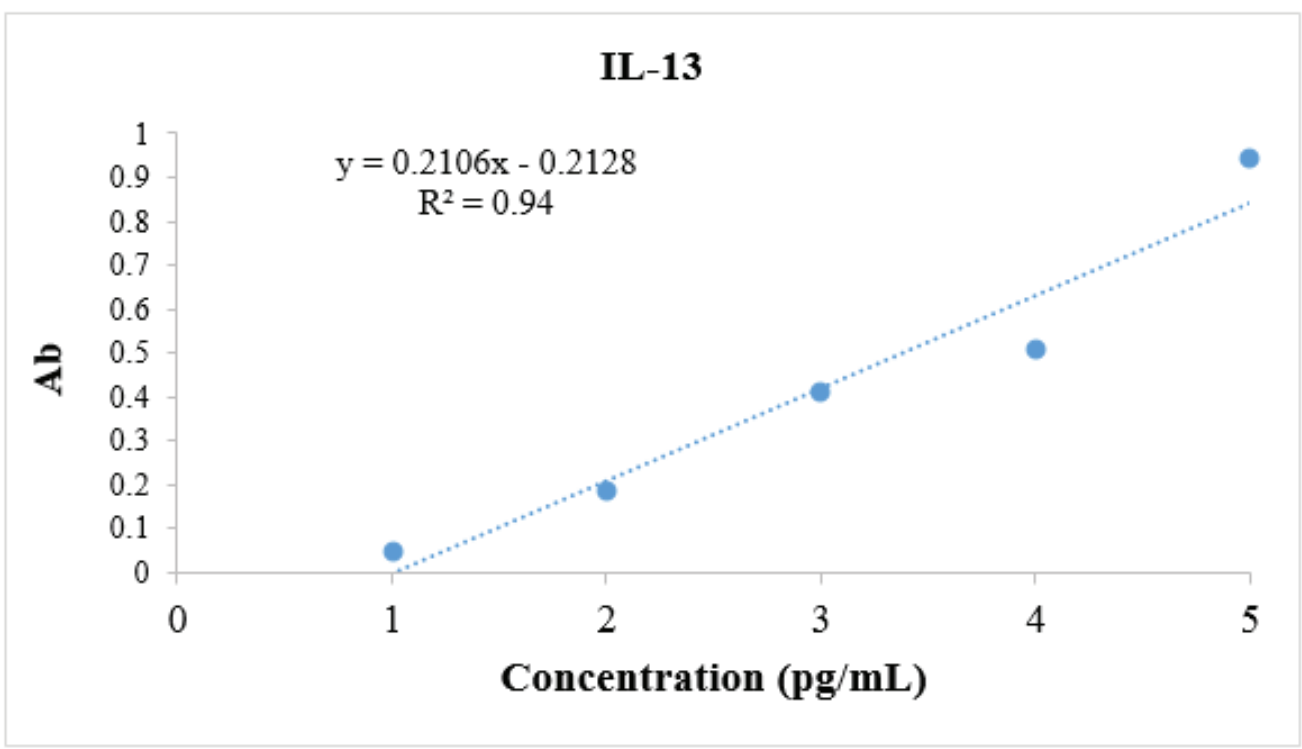

Fig. 2. Concentrations of IL-13 in patients infested with scabies. 


\section{Discussions}

Scabies is an important public health problem, not only for the individuals concerned, but also for their families and communities ${ }^{[6]}$. The manifestations of scabies are mediated through inflammatory and allergic-like reactions to mite products, leading to intensely pruritic skin lesions ${ }^{[7]}$. Both humoral and cellular immune responses against the mite antigens are developed ${ }^{[8]}$.

The mites hosting under the cuticle can produce soluble antigens via saliva, feces, and other secretions. In addition, various antigens can be released by dead and disintegrated mites. These antigens are probably more important and have greater pathogenic effects inducing immune and inflammatory responses of the human body than live mites. The antigens can spread to the dermis through subcutaneous intercellular fluid and stimulate immune and inflammatory responses ${ }^{[9]}$.

Results of the current study indicated a significant increasing in the mean of total WBC in patients infested with scabies; these lead to an increase in of lymphocytes, neutrophils, eosinophil and basophils because the infection with this parasite causes stimulation immune system of host humeral and cellular ${ }^{[10]}$.

Previous studies reported increased in total leucocytes counts in patients infested with scabies as Shelley and Bart ${ }^{[11]}$ and Walton et al ${ }^{[8]}$

Cadman and Lawrence ${ }^{[12]}$ noticed high numbers of lymphocytes, monocytes, eosinophils and basophils in patients with scabies. The granulocytes are innate effector cells in the host immune defense against many multicellular parasites.

The current study reported significant increase in mean of eosinophil count for scabies patients when compared with control, this observation maybe attributed to allergy disorder which is one of symptoms of S. scabiei infection and may be due to cellular respond due to the parasite infestation ${ }^{[8]}$.

The extracts of dead or 1ive mites can influence the number of inflammatory cells in local tissues and blood circulation during immune or inflammatory responses of the host ${ }^{[13-15]}$.
The current study showed significant increase in the levels inflammatory mediators such as IL-5 and IL-13 in the serum of patient infested with scabies.

Arlian and Morgan ${ }^{[15]}$ showed that the infestation with $S$. scabiei stimulates dermal microvascular endothelial cells to produce various inflammatory mediators, such as IL-1, IL-6 , IL-8 , IL-10 , and TNF- $\alpha$, these mediators participate in the regulation of inflammatory and immune responses.

Cadman and Lawrence [12] noticed that the eosinophils, mast cells and basophils can be rapidly recruited to sites of infection and draining lymph nodes where they produce IL-4 and/or IL-13.. They acted as responsible for the initiation and ongoing regulation of Th2 responses.

\section{Conclusion}

The results of current study showed that the scabies infestation caused immunological reactions includes both cellular and humoral immune response in patients when compared with control. They had an important role in change of total and differential leukocytes and effect on the levels of inflammatory mediators such as IL-5 and IL-13in patient when compared with control.

Financial Disclosure: There is no financial disclosure.

Conflict of Interest: None to declare.

Ethical Clearance: All experimental protocols were approved under the College of Education for Pure Science and all experiments were carried out in accordance with approved guidelines.

\section{References}

1. Larry G. Arlian, Marjorie S. Morgan, S. Dean Rider Jr. Sarcoptes scabiei: genomics to proteomics to biology, Parasites \& Vectors,2016; 9:380.

2. Walton, S. F., D. Beroukas, P. Roberts-Thomson, and B. J. Currie.

3. New insights into disease pathogenesis in crusted (Norwegian) scabies: the skin immune response in crusted scabies. Br. J. Dermatol.2008;158:1247-1255.

4. Granholem J. M. and Oleszewaki G. J. Scabies Prevention and Control Manual. Michigan 
Department of Community Health. Version 1.0,2005; $57 \mathrm{pp}$.

5. Quihui-Cota L.; Méndez Estrada R. O.; AstiazaránGarcía H.; Morales-Figueroa G. G.; Moreno-Reyes M. J.; Cuadras-Romo D. and Canett-Romero R. Changes in serum zinc levels associatedwith giardiasis and dietary zinc intake in mice. Biol Trace Elem Res.2012; 145: 396-402 [PMID: 21952867 DOI: 10.1007/s12011-011- 9208-5.

6. Nutman, T. B. Evaluation and differential diagnosis of marked, persistent eosinophilia. Immunol Allergy Clin North Am. 2007;27(3): 529-549.

7. Clucas, D., K. Carville, C. Connors, B. Currie, J. Carapetis, and R. Andrews. Disease burden and health-care clinic attendances for young children in remote Aboriginal communities of northern Australia. Bull. World Health Organ.2008; 86:241320.

8. Roberts, L. J., S. E. Huffam, S. F. Walton, and B. J. Currie. Crusted scabies: clinical and immunological findings in seventy-eight patients and a review of the literature. J. Infect.2005; 50:375-381.

9. Walton, S. F.; Pizzutto, S.; Slender, A.; Viberg, L.; Holt, D.; Hales, B. J.; Kemp, D. J.; Currie, B. J.; Rolland, J. M. and Hehir, R. O. Increased allergic immune response to Sarcoptes scabiei antigens in crusted versus ordinary Scabies. Clinical and Vaccine Immunology.2010; 17(9): 1428-1438.
10. Heukelbach J, Feldmeier H. Scabies. Lancet.2006; 367: 1767-1774.

11. Onoja, ibe remigius. cutaneous and systemic pathologic responses of the west frican dwarf goat to sarcoptes scabiei infestation .university of Nigeria, nsukka.2013;1-87.

12. Shelley, F. W. and Bart, J. C. Problems in diagnosing scabies, a global disease in human and animal populations. Clinic. Microbiol. Revi. 2007; 20 (2): 268-279.

13. Cadman, E. T. and Lawrence, R. A. Granulocytes: effector cells or immunomodulators in the immune response to helminth infection? Parasite Immunol. 2010; 32: 1-19.

14. Arlian LG, Vyszenski-Moher DL, Rapp CM, Hull BE. Production of IL-1 alpha and IL-1 beta by human skin equivalents parasitized by Sarcoptes scabiei. J Parasitol.1996; 82: 719-723.

15. Arlian LG, Morgan MS. Serum antibody to Sarcoptes scabiei and house dust mite prior to and during infestation with S. scabiei . Vet Parasitol.2000; 90: 315-326.

16. Arlian LG, Morgan MS, Neal JS. Modulation of cytokine expression in human keratinocytes and fibroblasts by extracts of scabies mites. Am J Trop Med Hyg.2003; 69: 652-656. 